\title{
Model of Potassium Dynamics in the Central Nervous System
}

\author{
LOUIS L. ODETTE ${ }^{1}$ AND ERIC A. NEWMAN ${ }^{2}$ \\ ${ }^{1}$ Applied Expert Systems, Inc., Cambridge, Massachusetts 02142; ${ }^{2}$ Eye Research Institute, \\ Boston, Massachusetts 02114
}

\begin{abstract}
KEY WORDS Glial cells, Astrocytes, Potassium homeostasis, Potassium spatial buffering, Ion diffusion, Computer model
\end{abstract}

\begin{abstract}
A one-dimensional numerical model of potassium dynamics in the central nervous system is developed. The model incorporates the following physiological processes in computing spatial and temporal changes in extracellular $\mathrm{K}^{+}$concentration, $\left[\mathrm{K}^{+}\right]_{0}: 1$ ) the release of $\mathrm{K}^{+}$from $\mathrm{K}^{+}$sources into extracellular space, 2) diffusion of $\mathrm{K}^{+}$through extracellular space, 3) active uptake of $\mathrm{K}^{+}$into cells and blood vessels, 4) passive uptake of $\mathrm{K}^{+}$into a cellular distribution space, and 5) the transfer of $\mathrm{K}^{+}$by $\mathrm{K}^{+}$spatial buffer current flow in glial cells. The following tissue parameters can be specified along the single spatial dimension of the model: 1 ) the volume fraction and tortuosity of extracellular and glial cell spaces, 2) the volume fraction of the cellular distribution space, 3) rate constants of active uptake and passive uptake processes, and 4) glial cell membrane conductance. The model computes variations in $\left[\mathrm{K}^{+}\right]_{0}$ and current flow through glial cells for three tissue geometries: 1) planar geometry (the retina and the surface of the brain), 2) cylindrical geometry (tissue surrounding a blood vessel), and 3) spherical geometry (tissue surrounding a point source of $\mathrm{K}^{+}$). For simple sources of $\mathrm{K}^{+}$, the performance of the model matches that predicted from analytical equations. Simulations of previous ion dynamics experiments indicate that the model can accurately predict ion diffusion and $\mathrm{K}^{+}$current flow in the brain. Simulations of electroretinogram generation and $\mathrm{K}^{+}$ siphoning onto blood vessels suggest that unanticipated $\mathrm{K}^{+}$dynamics mechanisms may be operating in the central nervous system.
\end{abstract}

\section{INTRODUCTION}

The concentration of ions, neurotransmitters, and other neuroactive substances varies widely, both tem. porally and spatially, in the extracellular space of the brain. The fate of these substances in the interstitium is important to the functioning of the central nervous sys. tem (CNS). Potassium ions are of particular interest. Extracellular $\mathrm{K}^{+}$concentration $\left(\left[\mathrm{K}^{+}\right]_{0}\right)$ varies widely with changes in neuronal activity (Somjen, 1979). Sensory stimulation raises $\left[\mathrm{K}^{+}\right]_{\mathrm{o}}$ by $1 \mathrm{mM}$ or more from a resting level of $3 \mathrm{mM}$ while tetanic stimulation in creases $\left[\mathrm{K}^{+}\right]_{0}$ to more than $10 \mathrm{mM}$. Variations in $\left[\mathrm{K}^{+}\right]_{0}$ have profound effects on neuronal excitability, modulating such processes as synaptic transmission and the initiation and propagation of action potentials (Somjen, 1979).

It is generally believed that $\left[\mathrm{K}^{+}\right]_{0}$ levels in the CNS are regulated within close bounds so that CNS function is not adversely affected (Cserr, 1986; Nicholson, 1980). Several mechanisms are thought to aid in regulating $\left[\mathrm{K}^{+}\right]_{0}$. These include: 1) diffusion of excess $\mathrm{K}^{+}$through extracellular space, 2) active reuptake of $\mathrm{K}^{+}$by active neurons, 3) active uptake of $\mathrm{K}^{+}$by other neurons and glial cells, 4) passive uptake of $\mathrm{K}^{+}$into neurons and glial cells, 5) spatial buffering and siphoning of $\mathrm{K}^{+}$by glial cells, and (perhaps) 6) active uptake of $\mathrm{K}^{+}$by blood vessels. Little is known about the relative importance of each of these mechanisms in regulating $\left[\mathrm{K}^{+}\right]_{0}$. Undoubtedly, the significance of each mechanism varies depending on the spatial and temporal characteristics of the $\left[\mathrm{K}^{+}\right]_{0}$ increase (Gardner-Medwin, 1986).

Received December 18, 1987; accepted February 18, 1988.

Address reprint requests to Eric A. Newman, Eye Research Institute, 20 Staniford Street, Boston, MA 02114. 
TABLE 1. Tissue parameters used in the model

\begin{tabular}{|c|c|c|c|}
\hline Abbreviation & Units & Parameter & $\begin{array}{l}\text { Nominal } \\
\text { value }\end{array}$ \\
\hline$\alpha$ & & Extracellular space volume fraction & 0.2 \\
\hline$\alpha_{\text {distr }}$ & & Distribution space volume fraction & 0.8 \\
\hline$\alpha_{\text {glia }}$ & & Glial cell volume fraction & 0.2 \\
\hline$\lambda^{b+a}$ & & Tortuosity factor & 1.55 \\
\hline$\lambda_{\text {glia }}$ & & Glial cell tortuosity factor & 1.55 \\
\hline$D^{-11 a}$ & $\mathrm{~cm}^{2} \mathrm{~s}^{-1}$ & Diffusion coefficient in saline & $210^{-5}$ \\
\hline$F$ & C mole ${ }^{-1}$ & Faraday constant & $96.510^{3}$ \\
\hline gglia & $\mathrm{S} \mathrm{cm}^{-3}$ & Glial cell membrane conductance & 0.62 \\
\hline $\mathrm{I}^{\mathrm{I}}$ & $\mathrm{A} \mathrm{cm}-2$ & Imposed current across tissue & 0 \\
\hline$\left[\mathrm{K}^{+}\right]_{0}$ & $\mathrm{mM}$ & Extracellular $\mathrm{K}^{+}$concentration & 3 \\
\hline$\left[\mathrm{K}^{+}\right]_{\text {init }}$ & $\mathrm{mM}$ & Initial extracellular $\mathrm{K}^{+}$concentration & 3 \\
\hline$\left[\mathrm{K}^{+}\right]_{\mathrm{i}}$ & $\mathrm{mM}$ & Intracellular $\mathrm{K}^{+}$concentration & 100 \\
\hline$\left[\mathrm{K}^{+}\right]_{\text {dist }}$ & $\mathrm{mM}$ & Distribution space $\mathrm{K}^{+}$concentration & 3 \\
\hline $\mathrm{r}$ & cm & Distance & \\
\hline $\mathrm{R}$ & $\mathrm{Jmole}^{-1} \mathrm{~K}^{-1}$ & Gas constant & 8.32 \\
\hline$t$ & $\mathrm{~s}$ & Time & \\
\hline $\mathrm{T}$ & K & Temperature & 290 \\
\hline rate $_{\text {distr }}$ & $\mathrm{s}^{-1}$ & $\begin{array}{l}\text { Rate constant, uptake into } \\
\text { distribution space }\end{array}$ & 0.2 \\
\hline pumpmax $_{\max }$ & $\mathrm{nmol} \mathrm{cm}-3 \mathrm{~s}^{-1}$ & $\begin{array}{l}\text { Maximal rate, active uptake into } \\
\text { neurons, glia, and endothelial cells }\end{array}$ & 0 \\
\hline source $_{K}$ & $\mathrm{mM} \triangle \mathrm{r}^{-1} \Delta \mathrm{t}^{-1}$ & $\mathrm{~K}^{+}$source & \\
\hline $\mathrm{RT} / \mathrm{F}$ & $\mathrm{mV}$ & Combined constant & 25 \\
\hline V & $\mathrm{mV}$ & Glial $\mathrm{K}^{+}$equilibrium potential & -87.7 \\
\hline
\end{tabular}

A promising approach to determining the effectiveness of each of these $\mathrm{K}^{+}$regulatory mechanisms is to model their effects in a quantitative fashion. This has been done in a number of instances, most notably by Gardner-Medwin (1983). In previous studies, $\mathrm{K}^{+}$clearance mechanisms have been modeled in an analytical fashion (Brew and Attwell, 1985; Coles, 1985; Coles and Orkand, 1985; Coles and Tsacopoulos, 1979; Dietzel et al., 1980; Eberhardt and Reichenbach, 1987; GardnerMedwin, 1983, 1986; Gardner-Medwin et al., 1981; Lux and Neher, 1973; Nicholson and Phillips, 1981). This approach has been useful but is limited because the analysis becomes unwieldy as additional processes are included in the modeled system. In addition, it is difficult to model physiological processes accurately that are spatially heterogeneous with analytical methods. For instance, diffusion through neural tissue of varying geometry or $\mathrm{K}^{+}$current flow through glial cells having a nonuniform $\mathrm{K}^{+}$conductance distribution leads to variable coefficient differential equations that are difficult to solve analytically.

To avoid the limitations inherent in analytical methods, we have chosen to analyze $\mathrm{K}^{+}$dynamics in the CNS using numerical techniques. We present below a description of our model of $\mathrm{K}^{+}$dynamics in the CNS, the numerical methods used to create the model, and results obtained using the model system. A description of some aspects of the model has appeared previously (Newman and Odette, 1984).

\section{THE MODEL}

The model describes $\mathrm{K}^{+}$dynamics along a single spatial dimension within the CNS. The constraint of a single dimension has the advantage of simplifying and shortening calculations significantly but has the disadvantage of limiting the complexity of conditions that can be modeled. As will be demonstrated below, however, it is possible to model a wide variety of conditions and tissue geometries in a one-dimensional system. De- pending on the value of a single scaling parameter, planar geometry (the retina or the surface of the brain), cylindrical geometry (brain tissue surrounding a blood vessel), or spherical geometry (brain tissue surrounding a point source of $\mathrm{K}^{+}$) can be accurately modeled in one dimension.

\section{Tissue parameters}

Model parameters are outlined in the following paragraphs and are summarized in Table 1 . The processes that control $\left[\mathrm{K}^{+}\right]_{\mathrm{o}}$ are indicated diagrammatically in Figure 1.

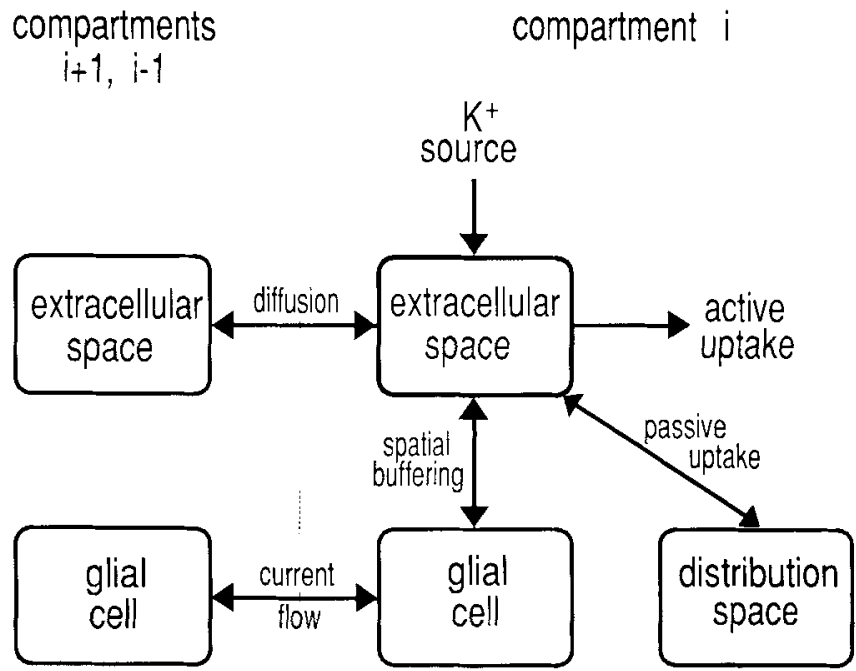

Fig. 1. Flow chart summarizing the $\mathrm{K}^{+}$dynamics processes simulated in the computer model. Spatial compartments included in the simulations are indicated by boxes. Processes leading to alterations in $\left[\mathrm{K}^{+}\right]_{0}$ are indicated by arrows. Compartments in spatial interval i lie to the right of the figure while compartments adjacent to those in $i$ (compartments $i+1, i-1$ ) lie to the left. 


\section{Distance (designated r; units: cm)}

The single spatial dimension of the model is a linear representation of space. When a planar geometry is modeled, $r$ represents depth from the surface of the tissue. In cylindrical and spherical geometries, $r$ represents distance along a radius, with $r=0$ representing the center of symmetry. Along $r$, space is divided into evenly spaced steps or intervals each having the length $\Delta \mathrm{r}$.

\section{Time (t, units: s)}

Time is divided into equally spaced intervals, designated $\Delta t$. Computations are made for each $\Delta t$ interval.

The following tissue parameters are specified for each spatial interval along $r$.

\section{Extracellular potassium concentration $\left(\left[\mathrm{K}^{+}\right]_{0}[\mathbf{r}, \mathbf{t}]\right.$; units: $\mathbf{m M}$ )}

$\left[\mathrm{K}^{+}\right]_{\mathrm{o}}$ at $\mathrm{t}=0$ (designated $\left[\mathrm{K}^{+}\right]_{\text {init }}$ ) is typically set to $3 \mathrm{mM}$ for all extracellular spatial compartments. As described below, $\left[\mathrm{K}^{+}\right]_{0}$ varies as a function of both $r$ and $t$.

\section{Intracellular glial cell potassium concentration $\left(\left[\mathbf{K}^{+}\right]_{i}\right.$; units: $\left.\mathbf{m M}\right)$}

$$
\left[\mathrm{K}^{+}\right]_{\mathrm{i}}=100 \mathrm{mM} \text { and does not vary with } \mathrm{r} \text { or } \mathrm{t} \text {. }
$$

\section{Distribution space potassium concentration ( $\left[\mathbf{K}^{+}\right]_{\text {distr }}[\mathbf{r}, \mathrm{t}]$; units: $\mathbf{m M}$ )}

$\left[\mathrm{K}^{+}\right]_{\text {distr }}$ is initially set to $\left[\mathrm{K}^{+}\right]_{\text {init }}$, typically $3 \mathrm{mM}$, and can vary with $r$ and $t$ as defined by equation 7 below.

\section{Potassium sources (source ${ }_{K}[r, t]$; units: $m M r^{-1} \Delta t^{-1}$ )}

An efflux of $\mathrm{K}^{+}$into extracellular space in the model simulates the release of $\mathrm{K}^{+}$by active neurons. The magnitude, time course, and spatial extent of a $\mathrm{K}^{+}$ source can be specified in the model. A source $\mathrm{K}_{\mathrm{K}}$ of 1 raises $\left[\mathrm{K}^{+}\right]_{0}$ by $1 \mathrm{mM}$ in compartment $r_{i}$ in the interval $\Delta \mathrm{t}$.

\section{Extracellular space volume fraction $(\alpha[\mathrm{r}]$, dimensionless)}

For each spatial step, the volume occupied by extracellular space is specified as a fraction of the total tissue volume. This quantity, commonly denoted $\alpha$ (Nicholson and Phillips, 1981) can vary from 0.025 in the nuclear layers of the retina (Karwoski et al., 1985a) to 1.0 in the vitreous humor of the eye and in the cerebrospinal fluid (CSF).
Ion diffusion coefficient (D[r] units: $\mathrm{cm}^{\mathbf{2}} \mathrm{s}^{-1}$ )

$\mathrm{D}$ is the diffusion coefficient of an ion in saline. $\mathrm{D}=$ $2 \cdot 10^{-5}$ for $K^{+}$.

\section{Extracellular space tortuosity factor $(\lambda[r]$, dimensionless)}

The convoluted (tortuous) geometry of extracellular space lengthens the effective pathway for ion diffusion by a factor $\lambda$ (Nicholson and Phillips, 1981). In the model $\lambda=1.55$ within neural tissue and $\lambda=1$ in the CSF and in the vitreous humor of the eye. $\lambda$ is incorporated into calculations of diffusion by modifying the $\mathrm{K}^{+}$diffusion coefficient as follows,

$$
\mathrm{D}^{*}=\mathrm{D} / \mathrm{\lambda}^{2},
$$

where $D^{*}$ is the effective diffusion coefficient and $\lambda$ is the tortuosity factor.

\section{Intracellular glial cell tortuosity factor $\left(\lambda_{\mathrm{glia}}[\mathrm{r}]\right.$,} dimensionless)

Measurements of ion diffusion within cells (Kushmerick and Podolsky, 1969; Mastro and Keith, 1984) indicate that $\mathrm{D}$ for ions and small molecules is reduced from the value in saline by approximately the same degree inside cells as it is in the extracellular space of the brain (two- to threefold). For simplicity, $\lambda_{\text {glia }}$ is set to $\lambda$ in the model.

\section{Passive uptake space volume fraction $\left(\alpha_{\text {distr }}[r]\right.$,} dimensionless)

This term represents the fraction of the total tissue volume into which excess extracellular $\mathrm{K}^{+}$can be redistributed (Gardner-Medwin, 1983). In practice, it represents the volume fraction of neurons and glial cells that passively take up $\mathrm{K}^{+}$. The sum of $\alpha$ and $\alpha_{\text {distr }}$ in our model is equivalent to the distribution space of GardnerMedwin (1983).

\section{Passive uptake rate constant (rate distr $_{[}[\mathrm{r}]$, units: $\mathrm{s}^{-1}$ )}

This term specifies the rate at which $\mathrm{K}^{+}$enters the passive uptake distribution space from extracellular space. In the brain, this rate is determined principally by the conductance of neurons and glial cells to $\mathrm{K}^{+}$and to its counterions.

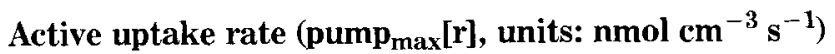

This term describes the combined effect of reuptake of $\mathrm{K}^{+}$by activated neurons, the active uptake of $\mathrm{K}^{+}$by other neurons and glial cells, and the active uptake of $\mathrm{K}^{+}$by vascular endothelial cells. The term represents the maximal activity of the $\mathrm{Na}^{+}-\mathrm{K}^{+}$ATPase per unit 
volume of tissue. The actual pumping rate varies linearly with $\left[\mathrm{K}^{+}\right]_{0}$ in the range of 0 to $2\left[\mathrm{~K}^{+}\right]_{\text {init }}$ (see equation 8), approximating the regulatory effect of $\left[\mathrm{K}^{+}\right]_{\mathrm{o}}$ on the ATPase. The sensitivity of the ATPase to changes in internal $\left[\mathrm{Na}^{+}\right]$and $\left[\mathrm{K}^{+}\right]$is not simulated in the model. The endothelial cell component of active uptake simulates the transport of $\mathrm{K}^{+}$from the CNS into the blood by vascular endothelial cells (Betz et al., 1980). (The active transport of $\mathrm{K}^{+}$into the blood is believed to be relatively unimportant in the short-term regulation of $\left[\mathrm{K}^{+}\right]_{\mathrm{o}}$; A.L. Betz, personal communication.)

\section{Intracellular glial space volume fraction $\left(\alpha_{\text {glia }}[r]\right.$, dimensionless)}

This term specifies the volume occupied by glial cells as a function of total tissue volume. In combination with $\mathrm{g}_{\text {glia, }}$, this term largely determines the glial cell space constant. When modeling a syncytium of glial cells coupled together by electrical junctions, $\alpha_{\text {glia }}$ is adjusted to provide the appropriate space constant for the syncytium.

\section{Glial cell membrane conductance ( $g_{\text {glia }}[r]$, units:}

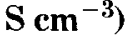

This term specifies the total membrane conductance of glial cells contained within a unit volume of tissue. It is equivalent to the product of the specific membrane conductance $\left(\mathrm{S} \mathrm{cm}^{-2}\right)$ and the total area of membrane contained in a unit volume $\left(\mathrm{cm}^{2} \mathrm{~cm}^{-3}\right)$. If the input conductance of glial cells is $25 \cdot 10^{-9} \mathrm{~S}$ cell ${ }^{-1}$ (Newman, 1986) and glial cells have a density of $25 \cdot 10^{6}$ cell cm$^{-3}$ (Pope, 1978), then glia $=0.62 \mathrm{~S} \mathrm{~cm}^{-3}$.

\section{Imposed current (I[t], units: $\left.A \mathbf{~ c m}^{-2}\right)$}

This term specifies the magnitude of a current applied externally to the model system. In essence, the two boundaries of the modeled tissue are current-clamped, with I describing the magnitude of the current flowing into the system from the tissue surface and flowing out from the other end of the tissue. In most cases $I=0$ (no externally imposed current).

\section{Scaling factor (scale[r], units: $\mathbf{c m}^{2}$ )}

$\alpha, \alpha_{\text {distr }}, \alpha_{\text {glia }}, \mathrm{g}_{\text {glia }}$, and pump max $_{\text {mat }}$ for each spatial interval are multiplied by a factor that correctly scales these values for the appropriate system geometry. The scaling factor is a function of $r$, the distance along the single dimension of the model, and is proportional to the volume of the tissue at the distance $\mathrm{r}$. Scale[r] is defined in equations 2,3 , and 4 below.

\section{Tissue geometry}

\section{Planar geometry}

When modeling tissue with planar geometry, such as the retina and the surface of the brain, the scaling factor "scale" is independent of $\mathrm{r}$ :

$$
\text { scale }=1 \mathrm{~cm}^{2}
$$

If a single spatial interval along $r(\Delta r)$ has the length $10^{-4} \mathrm{~cm}$, or $1 \mu \mathrm{m}$, the total tissue volume contained within that interval is the product of $\Delta r$ and scale, or $10^{-4} \mathrm{~cm}^{3}$. The volume of extracellular space can be calculated by taking the product of $\Delta \mathrm{r}, \alpha$, and scale. If $\alpha=0.2$, the volume of extracellular space within a single spatial interval is $10^{-4} \mathrm{~cm} \cdot 0.2 \cdot 1 \mathrm{~cm}^{2}$, or $0.2 \cdot 10^{-4}$ $\mathrm{cm}^{3}$. Similarly, glial cell conductance is calculated by taking the product of $\Delta \mathrm{r}, \mathrm{g}_{\mathrm{glia}}$, and scale. If $\mathrm{g}_{\mathrm{glia}}$ is $0.31 \mathrm{~S} \mathrm{~cm}^{-3}$, then the conductance contained in a single spatial interval is $10^{-4} \mathrm{~cm} \cdot 0.31 \mathrm{~S} \mathrm{~cm}^{-3} \cdot 1 \mathrm{~cm}^{2}$, or $0.31 \cdot 10^{-4} \mathrm{~S}$.

\section{Cylindrical geometry}

When modeling tissue with cylindrical symmetry, such as brain tissue surrounding a blood vessel, the scaling factor is defined as

$$
\text { scale }=r / \Delta r+1 / 2 \mathrm{~cm}^{2}
$$

where $r$ is the distance from the center of symmetry. Thus, given constant values of $\alpha$ and gglia, the extracellular volume and conductance contained within a single spatial step increases linearly with distance from the center of symmetry. (The factor $1 / 2$ in equation 3 corrects for the finite size, $\Delta r$, of the spatial intervals in the model.) For $\alpha=0.2$ and $\Delta \mathrm{r}=1 \mu \mathrm{m}$, the extracellular volume contained within a single spatial step is $2.1 \cdot 10^{-4}$ $\mathrm{cm}^{3}$ for $\mathrm{r}=10 \mu \mathrm{m}$ and $2.01 \cdot 10^{-3} \mathrm{~cm}^{3}$ for $\mathrm{r}=100 \mu \mathrm{m}$.

\section{Spherical geometry}

When modeling neural tissue having spherical symmetry, such as when dealing with a point source of $\mathrm{K}^{+}$, the scaling factor is defined as

$$
\text { scale }=(r / \Delta r)^{2}+r / \Delta r+1 / 3 \mathrm{~cm}^{2}
$$

For constant values of $\alpha$ and $\mathrm{g}_{\text {glia }}$, the extracellular volume and conductance increase as the square of the distance from the center of symmetry (with the terms $r$ / $\Delta r$ and $1 / 3$ correcting for the finite size of $\Delta r$ ). For gglia $=0.31 \mathrm{~S} \mathrm{~cm}^{-3}$ and $\Delta \mathrm{r}=1 \mu \mathrm{m}$, the total cell conductance contained within a step is $3.42 \cdot 10^{-3} \mathrm{~S}$ at $\mathrm{r}=10 \mu \mathrm{m}$ and $3.13 \cdot 10^{-1} \mathrm{~S}$ at $\mathrm{r}=100 \mu \mathrm{m}$.

\section{Boundary conditions}

A number of boundary regions must be specified depending on the geometry of the model system.

\section{Planar geometry}

When modeling the retina or the surface of the brain a boundary occurs at the surface of the tissue. This is specified in the model simply by varying values of $\alpha$ and 
$\lambda$ as a function of $r$. Thus, within the brain, $\alpha=0.2$ and $\lambda=1.55$, while, in the CSF, both $\alpha$ and $\lambda$ equal 1.

\section{Cylindrical and spherical geometries}

When modeling tissue with symmetry around a line or a point, diffusion and current flow only occur for $r>$ 0 . This boundary condition is satisfied by specifying (within matrix calculations) zero ionic flux and zero current for $r<0$.

\section{Glial cell geometry}

The boundaries of the glial cell in the model are defined by the conductance parameter, $g_{g l i a}$. In model simulations representing the retina, for instance, $g_{\text {glia }}>0$ for those spatial steps representing the neural retina (the location of the retinal glial cell) and $g_{g l i a}=0$ for those spatial steps representing the vitreous humor and subretinal space, where the glial cell is not present.

Glial cell endfeet are localized to one spatial interval and typically have a $\mathrm{g}_{\text {glia }}$ value 100 to 1,000 times greater than $g_{\text {glia }}$ for other cell regions. This large value represents the high $\mathrm{K}^{+}$conductance of the glial cell endfoot, which can contain up to $95 \%$ of total cell conductance (Newman, 1985, 1986). For instance, if $g_{g l i a}=$ 100 at the endfoot and $g_{\text {glia }}=1$ elsewhere in the glial cell, and if the glial cell extends over 101 spatial steps, $50 \%$ of the cell conductance will be localized to the endfoot.

In addition, $\alpha$ in the spatial interval representing the glial cell endfoot is different than $\alpha$ in other brain regions. When the endfoot lies at the surface of the retina or brain, $\alpha=1.0$ at the endfoot and represents the large extracellular volume of the vitreous and CSF, which lie adjacent to the endfoot. Conversely, when modeling glial cell endfeet terminating on blood vessels, $\alpha$ at the endfoot is small (typically 0.0002 ) and represents the small extracellular volume that separates the endfoot from blood vessels (Bradbury, 1979).

In certain instances, $g_{\text {glia }}$ must be scaled to represent glial cell geometry properly. For instance, in the cylindrical model representing glial cells surrounding blood vessels in the brain, a single blood vessel and a glial cell with a single endfoot is simulated. In such a model, the maximum value of $r$ used in the model typically equals $300 \mu \mathrm{m}$ (the radius of the modeled tissue). In the brain, however, approximately 225 capillaries lie within a cylinder of radius $300 \mu \mathrm{m}$ (Bar, 1980; Paulson and New. man, 1987). Thus, for all values of $r, g_{g l i a}$ must be divided by 225 to represent accurately the glial cell conductance associated with a single blood vessel.

\section{METHODS}

The single spatial dimension of the model is divided into a large number of steps or intervals (typically 160), each representing a length $\Delta r$. Each spatial interval has the following attributes (see Fig. 1): 1) An extracellular space compartment, described by $\alpha$ and $\lambda ; 2$ ) an intracellular glial cell space compartment, described by $\alpha_{\text {glia }}$ and $\lambda ; 3)$ an intracellular distribution space compart- ment, described by $\alpha_{\text {distr }}$ and rate distr ;) a glial cell membrane conductance, described by $\mathrm{g}_{\text {glia }} ; 5$ ) an active uptake process, described by pump max; and 6) a source of extracellular $\mathrm{K}^{+}$, described by source $\mathrm{K}$. For each time and space increment, the following calculations are made by the model:

1. $\left[\mathrm{K}^{+}\right]_{0}$ in the extracellular space compartment is adjusted according to source[r,t]. If, for instance, source $\left[\mathrm{i}, \mathrm{jl}\right.$ equals $1,\left[\mathrm{~K}^{+}\right]_{\mathrm{o}}$ in the ith spatial step is increased by $1 \mathrm{mM}$ at the jth time interval.

2. Diffusion of $\mathrm{K}^{+}$between extracellular compartments. Diffusion in the model is described by Fick's law,

$$
\left\{\mathrm{d}\left[\mathrm{K}^{+}\right]_{o} / \mathrm{dt}\right\}_{\text {diffusion }}=\mathrm{D}^{*}\left(\mathrm{~d}^{2}\left[\mathrm{~K}^{+}\right]_{\mathrm{o}} / \mathrm{dr}^{2}\right),
$$

where $D^{*}$ is the effective diffusion coefficient given in equation 1.

The effective diffusion coefficients of all ions in extracellular space are assumed to equal the effective diffusion coefficient of $\mathrm{K}^{+}$. Thus, diffusion potentials in extracellular space are ignored. $\left[\mathrm{K}^{+}\right]_{0}$ in each spatial interval is adjusted for $\mathrm{K}^{+}$sources, passive and active uptake, and current flow across the glial cell membrane prior to calculating diffusion fluxes.

3. Passive flow of $\mathrm{K}^{+}$between the extracellular compartment and the distribution space compartment. The subject of the flow of $\mathrm{K}^{+}$between extracellular space and a cellular distribution space has been treated in detail by Gardner-Medwin (1983). The equations describing this flux in our model are based on his analysis and are as follows.

$$
\begin{array}{r}
\left\{\mathrm{d}\left[\mathrm{K}^{+}\right]_{\mathrm{o}} \mathrm{dt}\right\}_{\text {passive uptake }} \\
=-\left(\left[\mathrm{K}^{+}\right]_{\mathrm{o}}-\left[\mathrm{K}^{+}\right]_{\text {distr }}\right) \text { rate }_{\mathrm{distr}},
\end{array}
$$

where

$$
\begin{aligned}
& \mathrm{d}\left[\mathrm{K}^{+}\right]_{\text {distr }} / \mathrm{dt} \\
& \quad=\left(\left[\mathrm{K}^{+}\right]_{0}-\left[\mathrm{K}^{+}\right]_{\text {distr }}\right)\left(\alpha / \alpha_{\text {distr }}\right) \text { rate } \\
& \text { distr. }
\end{aligned}
$$

Both $\left[\mathrm{K}^{+}\right]_{0}$ and $\left[\mathrm{K}^{+}\right]_{\text {distr }}$ are initially set to $\left[\mathrm{K}^{+}\right]_{\text {init }}$.

4. Active uptake of $\mathrm{K}^{+}$from the extracellular compartment. This term incorporates all active uptake processes, including uptake by neurons, glia and endothelial cells of blood vessels. It is described as follows:

$$
\begin{aligned}
& \left\{\mathrm{d}\left[\mathrm{K}^{+}\right]_{\mathrm{o}} / \mathrm{dt}\right\}_{\text {active uptake }} \\
& \quad=-\left(\left[\mathrm{K}^{+}\right]_{\mathrm{o}}-\left[\mathrm{K}^{+}\right]_{\text {init }}\right) \text { pump } \text { max } /\left(2 \alpha\left[\mathrm{K}^{+}\right]_{\text {init }}\right) .
\end{aligned}
$$

The active uptake process is proportional to $\left[\mathrm{K}^{+}\right]_{\mathrm{o}}$ and saturates when $\left[\mathrm{K}^{+}\right]_{0}$ reaches $2 \cdot\left[\mathrm{K}^{+}\right]_{\text {init. }}$. This is accomplished practically by limiting $\left\{\mathrm{d}\left[\mathrm{K}^{+}\right]_{0} / \mathrm{dt}\right\}_{\text {active uptake }}$ to a maximum value of - pump $_{\max }(2 \alpha)$. The active uptake process is assumed to be one-half maximal when $\left[\mathrm{K}^{+}\right]_{\mathrm{o}}$

$=\left[\mathrm{K}^{+}\right]_{\text {init }}$, and to be in equilibrium with other $\mathrm{K}^{+}$ fluxes at this point so that there is no net change in $\left[\mathrm{K}^{+}\right]_{0}$. Thus, $\left\{\mathrm{d}\left[\mathrm{K}^{+}\right]_{0} / \mathrm{dt}\right\}_{\text {active uptake }}=0$ when $\left[\mathrm{K}^{+}\right]_{0}=$ $\left[\mathrm{K}^{+}\right]_{\text {init, }}$ and $\left\{\mathrm{d}\left[\mathrm{K}^{+}\right]_{o} / \mathrm{dt}\right\}_{\text {active uptake }}=-\operatorname{pump}_{\max } /(2 \alpha)$ when $\left[\mathrm{K}^{+}\right]_{0}=2 \cdot\left[\mathrm{K}^{+}\right]_{\text {init. }}$.

$5 . \mathrm{K}^{+}$equilibrium potential across the glial cell membrane. The glial cell membrane is assumed to be exclu- 
sively permeable to $\mathrm{K}^{+}$. The $\mathrm{K}^{+}$diffusion potential is described by the Nernst equation

$$
\mathrm{V}=(\mathrm{RT} / \mathrm{F}) \ln \left(\left[\mathrm{K}^{+}\right]_{\mathrm{o}^{\prime}} /\left[\mathrm{K}^{+}\right]_{\mathrm{i}}\right),
$$

model. The general form of the predictor-corrector equations used in solving equation 13 as well as the matrix used to solve the mesh equations are presented in the Appendix of Newman and Odette (1984).

The following parameters are available as outputs of

where $\left[\mathrm{K}^{+}\right]_{\mathrm{i}}$ is the $\mathrm{K}^{+}$concentration in the intracellular glial cell compartment.

6. $\mathrm{K}^{+}$current across the glial cell membrane. Local variations in $\left[\mathrm{K}^{+}\right]_{o}$ generate variations in the local driving force for $\mathrm{K}^{+}$and result in current flow across the glial cell membrane. These currents, in turn, establish a current flow through the extracellular and intracellular compartments and across other regions of the glial cell membrane. These currents are calculated by solving for a series of mesh equations (see Newman and Odette,
1984 ). A mesh current is calculated for each spatial interval $\Delta \mathrm{r}$ and depends on 1) the difference between the membrane potential and the $\mathrm{K}^{+}$equilibrium potential, 2) the membrane conductance, $g_{g l i a}$, and 3) the conductance of the extracellular and intracellular compartments. The conductivity values of these two compartments are given by the relation

$$
\text { conductivity }\left(\mathrm{S} \mathrm{cm}^{-1}\right)=2 \mathrm{~F}\left(\left[\mathrm{~K}^{+}\right]+\left[\mathrm{Na}^{+}\right]\right) \mathrm{u}_{\mathrm{K}} \text {, }
$$

where $\mathrm{u}_{\mathrm{K}}$ is the mobility of $\mathrm{K}^{+}$, and the sum of $\left[\mathrm{K}^{+}\right]$ and $\left[\mathrm{Na}^{+}\right]$represents the total concentration of cations in the extracellular or intracellular compartments. Counterions to $\mathrm{K}^{+}$and $\mathrm{Na}^{+}$are assumed to have the same mobility and the same total concentration-thus, the factor 2 . The conductance of a spatial compartment is calculated,

conductance $(\mathrm{S})=$ conductivity $\alpha$ scale $/\left(\lambda^{2} \Delta \mathrm{r}\right)$.

7. $\left[\mathrm{K}^{+}\right]_{0}$ is adjusted for $\mathrm{K}_{+}$current flow across the glial cell membrane. Current across the glial cell membrane is carried by $\mathrm{K}^{+}$. Accordingly, $\left[\mathrm{K}^{+}\right]_{0}$ is adjusted for current flow by the relation

$$
\left\{\mathrm{d}\left[\mathrm{K}^{+}\right]_{\mathrm{o}} / \mathrm{dt}\right\}_{\text {flux }}=-\Delta \mathrm{Vg}_{\text {glia }} /(\mathbf{F} \alpha),
$$

where $\Delta \mathrm{V}$ is the difference between the membrane potential and the $\mathrm{K}^{+}$equilibrium potential. $\left[\mathrm{K}^{+}\right]_{\mathrm{i}}$ is assumed to remain constant; i.e., $\mathrm{K}^{+}$current across the glial cell membrane does not alter $\left[\mathrm{K}^{+}\right]_{\mathrm{i}}$. The capacitance of the glial cell membrane is ignored when calculating transmembrane potentials.

An equation describing the temporal and spatial changes in $\left[\mathrm{K}^{+}\right]_{0}$ in the model is obtained by combining equations $5,6,8$, and 12 :

$$
\begin{aligned}
& \mathrm{d}\left[\mathrm{K}^{+}\right]_{\mathrm{o}} / \mathrm{dt}= \\
& \mathrm{D}^{*}\left(\mathrm{~d}^{2}\left[\mathrm{~K}^{+}\right]_{\mathrm{o}} / \mathrm{dr}^{2}\right)-\left(\left[\mathrm{K}^{+}\right]_{\mathrm{o}}-\left[\mathrm{K}^{+}\right]_{\text {distr }}\right) \text { rate }_{\text {distr }} \\
& -\left(\left[\mathrm{K}^{+}\right]_{\mathrm{o}}-\left[\mathrm{K}^{+}\right]_{\text {init }}\right) \text { pump } \text { max }_{\max } /\left(2 \alpha\left[\mathrm{K}^{+}\right]_{\text {init }}\right) \\
& -\Delta \mathrm{Vg}_{\mathrm{glia}} /(\mathrm{F} \alpha) .
\end{aligned}
$$

The equation is solved numerically using a predictorcorrector method based on the Crank-Nicholson procedure (Ames, 1969). The Thomas tridiagonal algorithm (Carnahan et al., 1969) is used to solve the set of equations. Readers are referred to Newman and Odette (1984), who present a more detailed description of the numerical methods used to solve the equations of the the model: 1) $\left[\mathrm{K}^{+}\right]_{\mathrm{o}}$ in the extracellular space compartment, 2) voltage in the extracellular space compartment, 3 ) voltage in the intracellular glial cell compartment, and 4) current source-density magnitude for current flow across the glial cell membrane. Each of the above parameters can be expressed as 1) a function of $r$ at a particular time increment or 2) as a function of time at specified spatial increments. Output parameters are stored in binary files and can be plotted graphically on a computer monitor and on associated plotters and printers.

All calculations are made with software written in the $\mathrm{C}$ language. The program is run on an IBM XT-compatible personal computer equipped with a math coprocessor chip. Calculations take approximately $1.4 \mathrm{sec}$ per time step.

\section{RESULTS \\ Tests of the Model}

We have tested the accuracy of the model by imposing simple initial conditions on the system and comparing the resulting performance with that predicted analytically. Using this method, the performance of the following model components has been verified.

(11) Diffusion

Given an imposed $\mathrm{K}^{+}$source at $\mathrm{r}=0$ and $\mathrm{t}=0$, the $\mathrm{K}^{+}$concentration in time and space can be calculated analytically using the following equations (Crank, 1975):

Planar symmetry,

Cylindrical symmetry,

$$
\left[\mathrm{K}^{+}\right]_{0}=\mathrm{M} /(4 \pi \mathrm{Dt}) \exp \left(-\mathrm{r}^{2} / 4 \mathrm{Dt}\right)
$$

Spherical symmetry,

$$
\left[\mathrm{K}^{+}\right]_{0}=\mathrm{M} /\left[8(\pi \mathrm{Dt})^{1.5}\right] \exp \left(-\mathrm{r}^{2} / 4 \mathrm{Dt}\right)
$$

where $\mathrm{M}$ is the total quantity of $\mathrm{K}^{+}$at $\mathrm{r}=0$ and $t=0$. In equation 14, the planar solution, we assume that diffusion occurs in only one direction from the source, i.e., there is a diffusion boundary for $r<0$.

In computing the analytical equations, $M$ is set equal to the magnitude of the $\mathrm{K}^{+}$source in the model: the product of the source $(100 \mathrm{mM})$ and the volume of the spatial compartment at $\mathrm{r}=0(\Delta \mathrm{r} \alpha$ scale $)$. In these diffusion tests $\alpha=0.2$, and gglia, rate distr $_{\text {, }}$, and pump $\max$ are all set to zero so that diffusional forces alone influence $\left[\mathrm{K}^{+}\right]_{\text {. }}$.

A comparison between the model results and those predicted by equations 14, 15, and 16 is shown in Figure 2 (see also Table 2 ). $\Delta\left[\mathrm{K}^{+}\right]_{\mathrm{o}}$ vs. time is plotted for two fixed distances from the $\mathrm{K}^{+}$source $(50 \mu \mathrm{m}$ and $100 \mu \mathrm{m})$ and for tissue having planar symmetry (Fig. 2A), cylindrical symmetry (Fig. 2B) and spherical symmetry (Fig. 
TABLE 2. Values of tissue parameters used in the simulations illustrated in Figures 2-8

\begin{tabular}{|c|c|c|c|c|c|c|c|}
\hline Parameter & $\begin{array}{c}\text { Figure } \\
2 \\
\end{array}$ & $\begin{array}{c}\text { Figure } \\
3 \\
\end{array}$ & $\begin{array}{c}\text { Figure } \\
4 \\
\end{array}$ & $\begin{array}{c}\text { Figure } \\
5 \\
\end{array}$ & $\begin{array}{c}\text { Figure } \\
6 \\
\end{array}$ & $\begin{array}{c}\text { Figure } \\
7 \\
\end{array}$ & $\begin{array}{c}\text { Figure } \\
8 \\
\end{array}$ \\
\hline Tissue geometry & $\begin{array}{l}\text { Planar, } \\
\text { cylindr, and } \\
\text { spherical }\end{array}$ & Planar & Planar & Spherical & Planar & Cylindrical & Planar \\
\hline Source $_{K}$ & 100 at $r=0$ & 1 at $\mathrm{r}=250 \mu \mathrm{m}$ & 1 & 5,094 at $r=0$ & None & 1 for $\mathrm{r}>50 \mu \mathrm{m}$ & * \\
\hline$\alpha$ & 0.20 & 0.20 & 0.20 & 0.15 & 0.20 & 0.20 & $*$ \\
\hline$\lambda^{2}$ & 2.4 & 2.4 & 2.4 & 2.22 & 2.4 & 2.4 & 2.4 \\
\hline D & $210^{-5}$ & $210^{-5}$ & $210^{-5}$ & $1.310^{-5}$ & $210^{-5}$ & $210^{-5}$ & $210^{-5}$ \\
\hline$\alpha_{\text {distr }}$ & 0 & 0 & 0.80 & 0 & 0.80 & 0.80 & 0.80 \\
\hline Rate $_{\text {distr }}$ & 0 & 0 & 0.2 & 0 & 0.2 & 0.2 & 0.2 \\
\hline Pumpmax $_{\max }$ & 0 & 0 & 50,250 & 0 & 0 & 0 & 0 \\
\hline$\alpha_{\text {glia }}$ & 0.20 & 0.20 & 0.20 & 0.20 & 0.006 & 0.20 & 0.20 \\
\hline gglia & 0 & $\begin{array}{r}1,000 \text { at } r=20 \\
0.1 \text { at } r=120\end{array}$ & 0 & 0 & 0.044 & $\begin{array}{l}0.31 \\
*\end{array}$ & $*$ \\
\hline I & 0 & 0 & 0 & 0 & $-2.210^{-3}$ & 0 & 0 \\
\hline
\end{tabular}

*Values of these parameters are given in the figure legends.

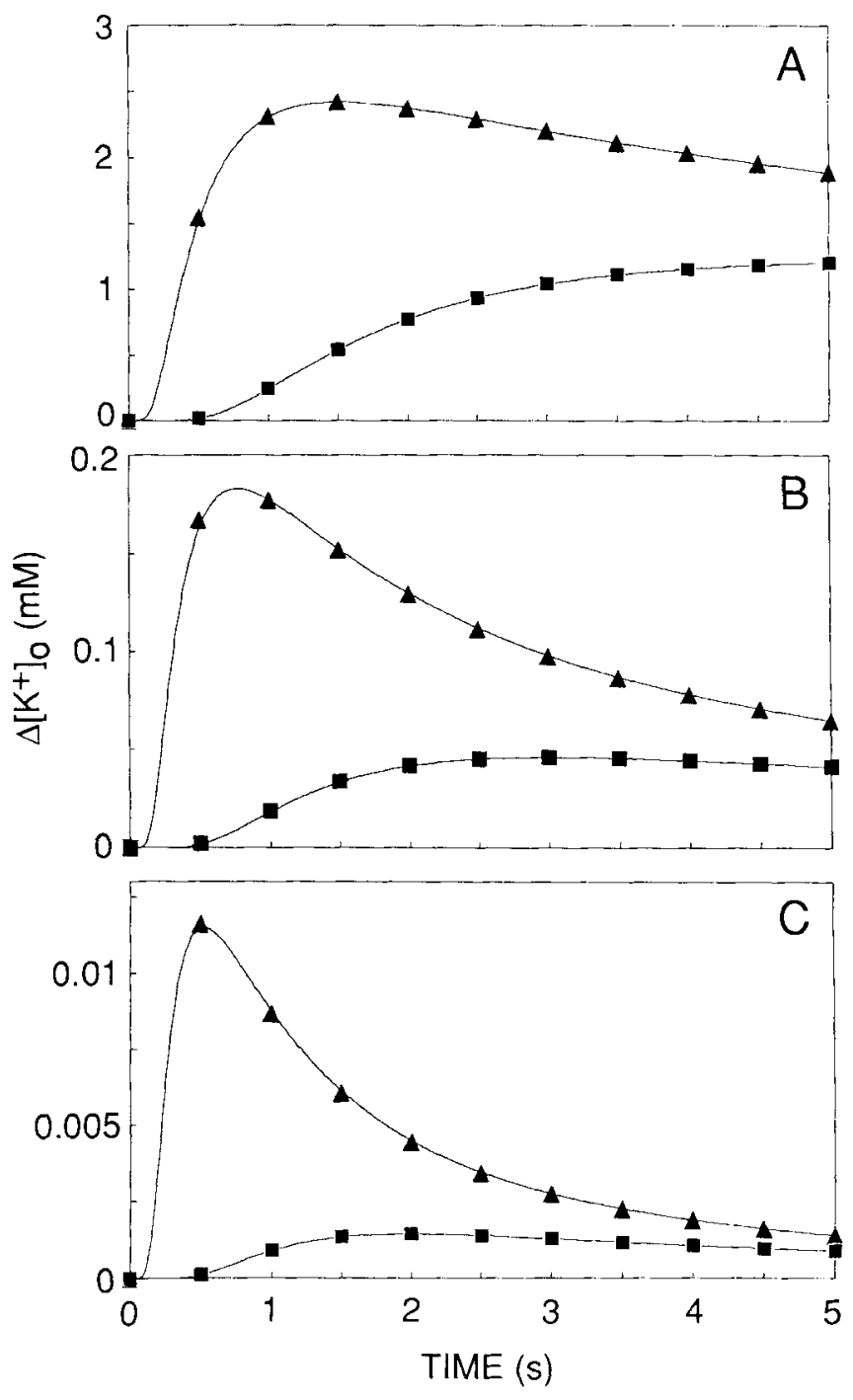

2C). The $\left[\mathrm{K}^{+}\right]_{0}$ values calculated by the model (smooth curves) are essentially identical to those predicted analytically (symbols) for all three system geometries. Peak magnitudes in the model simulations are within $0.7 \%$ of those calculated analytically in all cases. Note that as the tissue geometry changes from planar to cylindrical to spherical, the $\left[\mathrm{K}^{+}\right]_{\mathrm{o}}$ increase at 50 and $100 \mu \mathrm{m}$ from the $\mathrm{K}^{+}$source is severely attenuated. This attenuation is due to the large increase in the extracellular volume in the cylindrical and spherical models at these distances.

The diffusion process, as calculated by the model with planar geometry, was also tested using an extended $\mathrm{K}^{+}$ source and a spatial step in $\mathrm{K}^{+}$as the imposed $\mathrm{K}^{+}$ source. $\left[\mathrm{K}^{+}\right]_{0}$ values calculated by the model were nearly identical to those predicted analytically in these cases as well.

\section{Voltage and current flow}

The performance of many system processes can be tested by imposing an increase in $\left[\mathrm{K}^{+}\right]_{0}$ at a single spatial interval located at one end of the glial cell. This $\left[\mathrm{K}^{+}\right]_{0}$ increase depolarizes the glial cell and establishes a current flow through extracellular space. If gglia $=0$ everywhere except at the two ends of the cell, $\mathrm{K}^{+}$current will enter the cell at the $\mathrm{K}^{+}$source and exit from the other end of the cell. The resulting current flow generates a linear drop in voltage in extracellular space

Fig. 2. Diffusion of $\mathrm{K}^{+}$from a $\mathrm{K}^{+}$source at $\mathrm{r}=0 .\left[\mathrm{K}^{+}\right]_{0}$ at $50 \mu \mathrm{m}$ (A) and $100 \mu \mathrm{m}$ ( $\square$ ) from the source is plotted as a function of time. Continuous curves are $\Delta\left[\mathrm{K}^{+}\right]_{0}$ values calculated from the computer model. Symbols are values computed from equations 14,15 , and $16 . \mathrm{A}$ : Planar geometry. The $\mathbf{K}^{+}$source is a planar sheet of infinite extent. Diffusion occurs only to one side of the source. B: Cylindrical geometry. The $\mathrm{K}^{+}$source is a line of infinite extent. $\mathrm{C}$ : Spherical geometry. The $\mathrm{K}^{+}$source is a point. At both distances from the $\mathrm{K}^{+}$source and for all three system geometries, $\left[\mathrm{K}^{+}\right]_{0}$ values predicted by the model are essentially identical to those calculated from the analytic expressions. Except when otherwise noted, tissue parameters for the simulations illustrated in Figures 2-8 are given in Table 2. 

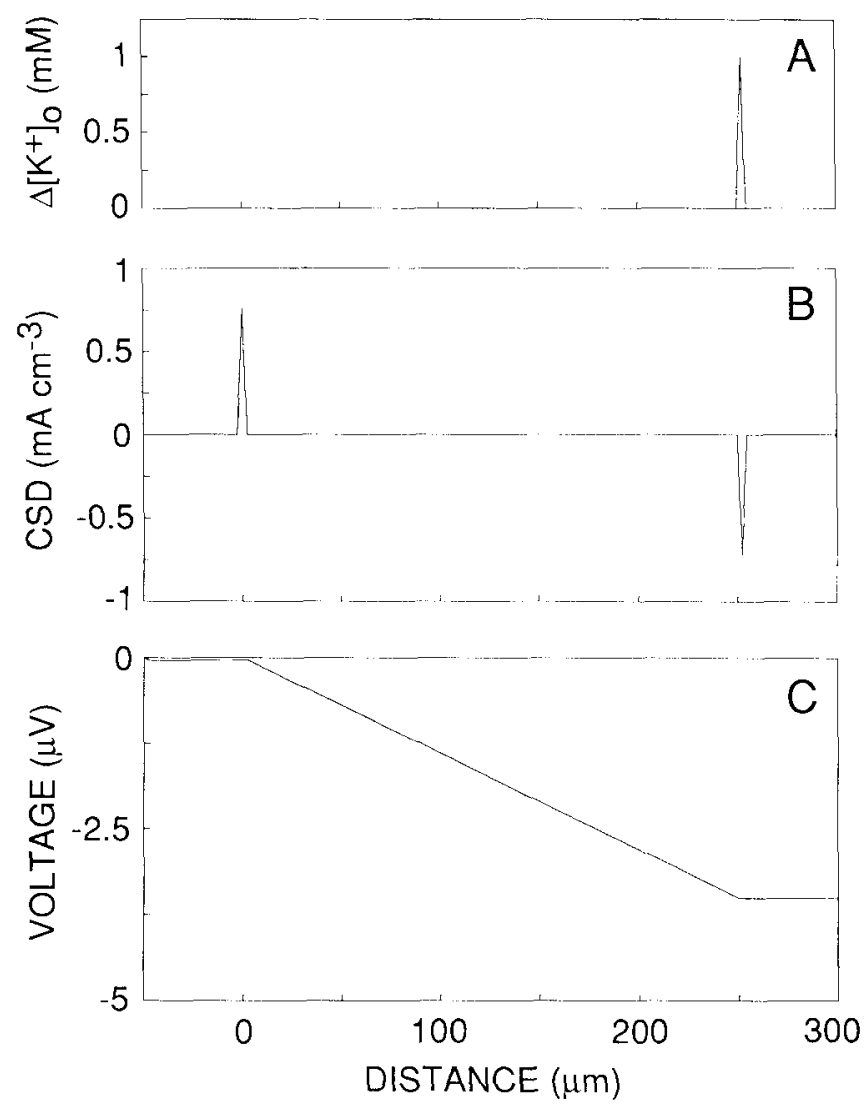

Fig. 3. Current flow through the model glial cell. A: $\mathrm{A} \mathrm{K}^{+}$source at $r=250 \mu \mathrm{m}$ raises $\left[\mathrm{K}^{+}\right]_{0}$ by $1 \mathrm{mM}$ in one spatial step. B: This $\left[\mathrm{K}^{+}\right]_{0}$ increase generates an influx of $\mathrm{K}^{+}$current into the glial cell in this spatial step (a negative current source-density, CSD) and an efflux of $\mathrm{K}^{+}$from the step at $0 \mu \mathrm{m}$ (a positive CSD). In this simulation $\mathrm{g}_{\mathrm{glia}}=0$ for all spatial steps except at 0 and $250 \mu \mathrm{m}$. Thus, CSD $=0$ except in these two intervals. C: Current flow through extracellular space from the current source at $\mathrm{r}=0 \mu \mathrm{m}$ to the current sink at $\mathrm{r}=250 \mu \mathrm{m}$ generates a linear drop in voltage through extracellular space. The magnitude of the voltage drop and the CSD values are nearly identical to those predicted based on $\mathrm{g}_{\mathrm{glia}}$ values and on the initial increase in $\left[\mathrm{K}^{+}\right]_{0}$ (see text).

between the current source and the current sink (given a planar tissue geometry). Various aspects of this simulation are illustrated in Figure 3. (Diffusion of $\mathrm{K}^{+}$from the initial $\mathrm{K}^{+}$source is minimized by making the time steps, $\Delta \mathrm{t}$, very small.)

The theoretical performance of the system under these conditions can be calculated from values of the model parameters. The magnitude of the initial current influx into the glial cell is calculated from Ohm's law, knowing the membrane conductance, gglia, and the driving force, $\Delta \mathrm{V}$, generated by the $\mathrm{K}^{+}$source. The linear drop of voltage in both extracellular and intracellular space is also calculated from Ohm's law, knowing the current and the conductances of the extracellular and intracellular compartments. In addition, changes in $\left[\mathrm{K}^{+}\right]_{0}$ produced by glial cell current can be assessed by noting how fast $\left[\mathrm{K}^{+}\right]_{0}$ increases or decreases at the location of the current source or current sink.

In the simulation illustrated in Figure 3, the initial, imposed $\left[\mathrm{K}^{+}\right]_{0}$ increase is $1 \mathrm{mM}$ (Fig. $\left.3 \mathrm{~A}\right)$; the glial

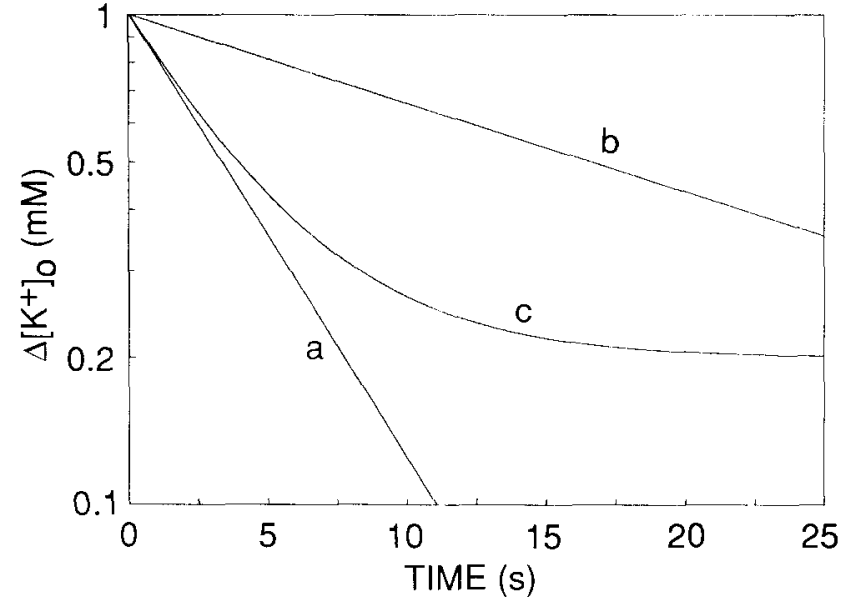

Fig. 4. Active and passive uptake of $\mathrm{K}^{+}$from extracellular space. $\Delta\left[\mathrm{K}^{+}\right]_{0}$ is plotted on a logarithmic scale as a function of time following an imposed, spatially uniform increase in $\left[\mathrm{K}^{+}\right]_{0}$ from 3 to $4 \mathrm{mM}$ at $\mathrm{t}=0$. $(\mathbf{a}, \mathbf{b})$ : Active uptake of $\mathrm{K}^{+}$produces an exponential decline in $\left[\mathrm{K}^{+}\right]_{0}$ to $\left[\mathrm{K}^{+}\right]_{\text {init }}\left(\Delta\left[\mathrm{K}^{+}\right]_{0}=0\right)$. The time constant of decay $(4.8 \mathrm{sec}$ in trace a and 24 sec in trace $b$ ) is inversely proportional to pump $p_{\max } \cdot$ pump $_{\max }=250$

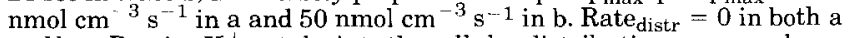
and b. c: Passive $\mathrm{K}^{+}$uptake into the cellular distribution space produces a non-exponential decline in $\left[\mathrm{K}^{+}\right]$. The slope of trace $c$ at $t=0$ indicates that the initial rate of decline has a time constant of 5 sec. However, the rate at which $\left[\mathrm{K}^{+}\right]_{0}$ declines is quickly reduced, and $\Delta\left[\mathrm{K}^{+}\right]_{0}$ levels off at $0.2 \mathrm{mM}$, an $80 \%$ reduction from the initial $\left[\mathrm{K}^{+}\right]_{0}$ increase. rate distr $=0.2$ $\mathrm{s}^{-1} ; \operatorname{pump}_{\max }=0$.

cell conductance is $2.5 \cdot 10^{-5} \mathrm{~S}$ at the $\mathrm{K}^{+}$source and $2.5 \cdot 10^{-1} \mathrm{~S}$ at the other end of the cell. The conductance of both intracellular and extracellular compartments is $5.14 \cdot 10^{-2} \mathrm{~S} \mathrm{~cm}^{-2}$ per $250 \mu \mathrm{m}$ length. Given these conditions, a current of $1.8 \cdot 10^{-7} \mathrm{~A}$ will be evoked $\left(0.72 \cdot 10^{-3}\right.$ $\mathrm{A} \mathrm{cm}^{-3}$; Fig. 3B) and a voltage drop across extracellular space of $3.5 \cdot 10^{-6} \mathrm{~V}$ per $250 \mu \mathrm{m}$ will be generated (Fig. $3 \mathrm{C})$. In addition, $\mathrm{K}^{+}$will accumulate in extracellular space (at the site of the current source) at a rate of 7.48 $10^{-4} \mathrm{M} \mathrm{s}^{-1}$ (assuming $\alpha=0.01$ ). The actual output of the model for each of these parameters was, in every instance, within $0.6 \%$ of the predicted value.

\section{Uptake processes}

Active and passive uptake processes in the model can be tested by imposing an instantaneous, spatially uniform increase in $\left[\mathrm{K}^{+}\right]_{0}$ at $t=0$ and noting the rate at which $\left[\mathrm{K}^{+}\right]_{0}$ decreases with time. When active uptake is tested under such conditions, $\left[\mathrm{K}^{+}\right]_{\mathrm{o}}$ decreases with an exponential time course having a time constant proportional to the reciprocal of pump $\max _{\text {max }}$ (Fig. 4a,b). Passive uptake, on the other hand, produces a non-exponential decrease in $\left[\mathrm{K}^{+}\right]_{o}$ (Fig. 4c). For passive uptake, $\left[\mathrm{K}^{+}\right]_{o}$ initially declines with a time constant equal to the recip-

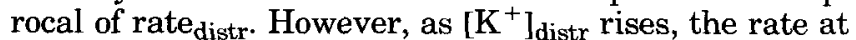
which $\left[\mathrm{K}^{+}\right]_{0}$ falls is reduced. $\left[\mathrm{K}^{+}\right]_{0}$ levels off at a value determined by the quantity $\alpha /\left(\alpha+\alpha_{\text {distr }}\right)$. In the example illustrated in Figure $4 \mathrm{c},\left[\mathrm{K}^{+}\right]_{0}$ levels out at $20 \%$ of the initial $\left[\mathrm{K}^{+}\right]_{0}$ increase $\left(\alpha=0.2\right.$ and $\left.\alpha_{\text {distr }}=0.8\right)$. If $\alpha_{\text {distr }} \gg \alpha$ (an unrealistic physiological condition), $\Delta\left[\mathrm{K}^{+}\right]_{\mathrm{o}}$ decreases to 0 during passive uptake with a simple exponential time course (data not shown). 


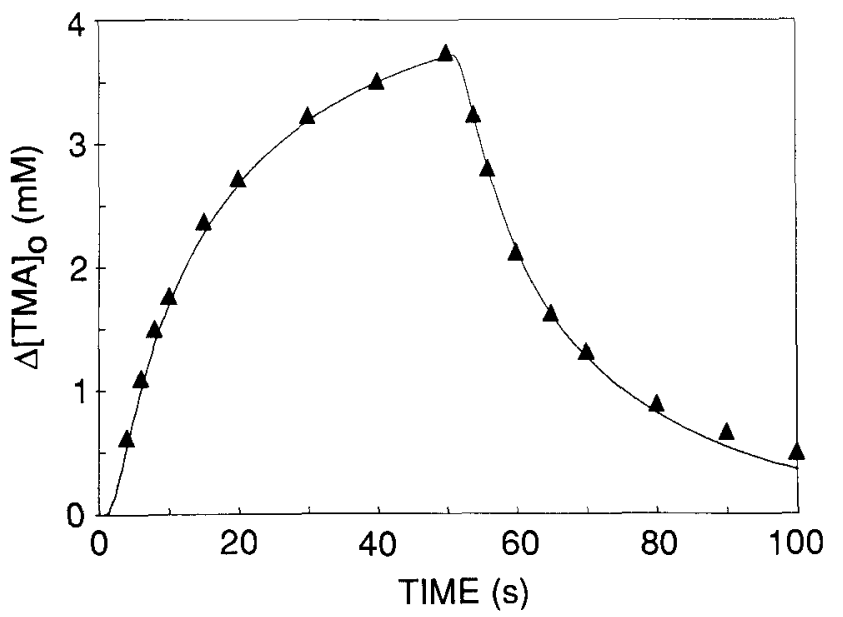

Fig. 5. Simulation of diffusion during the iontophoretic injection of tetramethylammonium (TMA) into the brain. Data points ( $\Delta$ ) are taken from the experiment of Nicholson and Phillips (1981; Fig. 3, 180 $\mathrm{nA}$ ). In that experiment TMA was injected into the brain for a 50-sec period. The build-up and decline of the ion was measured at a distance of $114 \mu \mathrm{m}$ from the TMA source using an ion-selective microelectrode. The smooth curve shows the [TMA] values at $114 \mu \mathrm{m}$ as calculated by the computer model, using the tissue parameters derived by Nicholson and Phillips. The model predicts the diffusion of TMA from a point source in the brain accurately.

\section{Simulations of Experimental Results}

We have used our model of $\mathrm{K}^{+}$dynamics to analyze the results of previous experiments that have measured ion diffusion in the brain. Nicholson and Phillips (1981) measured the diffusion of cations in the rat cerebellum using iontophoretic ejections from a micropipette and measuring the buildup of the ion at a fixed distance from the source with ion-selective microelectrodes.

The data points in Figure 5 reproduce the results of one of the experiments of Nicholson and Phillips (1981). In this experiment, tetramethylammonium (TMA) was ejected from a pipette for a 50-sec period, and the buildup of TMA was monitored at a distance of $114 \mu \mathrm{m}$. Nicholson and Phillips analyzed this experiment by assuming simple diffusion from a point source and then choosing values for $\alpha, \lambda$, and the transport number of TMA in the ejection pipette that best fit the results. Our own numerical model of diffusion from a point source (using a spherical geometry and their estimates of $\alpha, \lambda$, and transport number) fit the data points quite nicely (Fig. 5 , smooth curve), indicating that the computer model can accurately simulate ion diffusion in brain tissue.

The simulation of ion diffusion illustrated in Figure 5 assumes that there is no current flow through glial cells (glia are impermeable to TMA). A more complex situation is encountered when one deals with $\mathrm{K}^{+}$diffusion in the brain. One such experiment was conducted by Gardner-Medwin and Nicholson (1983). They passed a constant current across the surface of the cerebellar cortex of the rat and monitored changes in $\left[\mathrm{K}^{+}\right]_{0}$ within the cerebellum using an ion-selective microelectrode. The passage of current into the brain would produce no change in $\left[\mathrm{K}^{+}\right]_{0}$ if $\mathrm{K}^{+}$movement were restricted to

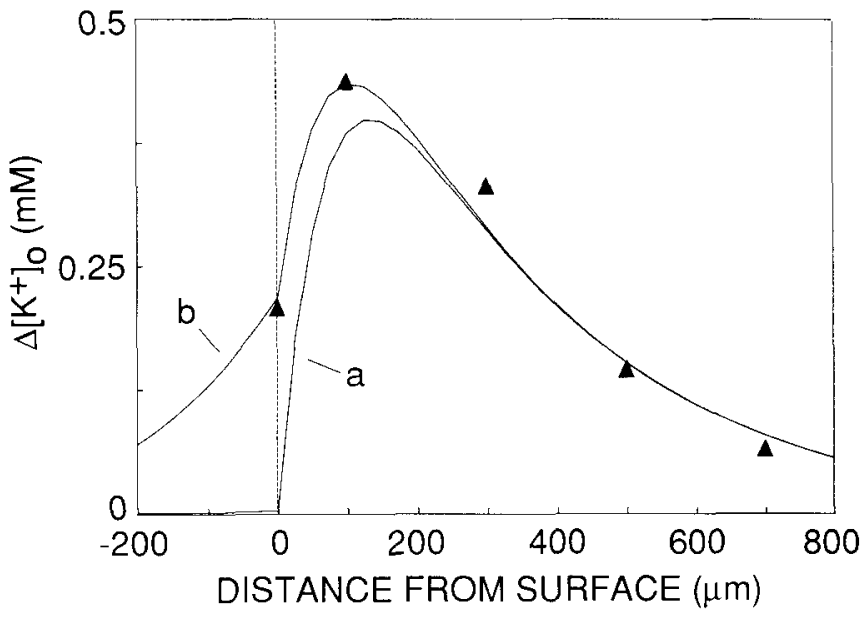

Fig. 6. Simulation of the build-up of $\left[\mathrm{K}^{+}\right]_{0}$ within the brain during the passage of current across the brain surface. Data points $(\boldsymbol{\Delta})$ are taken from the experiment of Gardner-Medwin and Nicholson (1983; Fig. 5D, negative current). In that experiment, a current was passed across the brain surface, and the resulting change in $\left[\mathrm{K}^{+}\right]_{0}$ was measured with an ion-selective microelectrode at various depths beneath the surface. The smooth curves show the $\Delta\left[\mathrm{K}^{+}\right]_{0}$ values calculated by the computer model. a: $\alpha=100$ for $r<0$; simulating the perfusion and mixing of the fluid bathing the surface of the brain. $b: \alpha=1$ for $\mathrm{r}<0$, simulating a significant unstirred layer of fluid adjacent to the brain surface. Simulation $b$ fits the data point at $\mathbf{r}=0$ much better than $a$, suggesting that during the experiment the fluid immediately adjacent to the brain surface was not stirred to a significant degree.

extracellular space. However, because a large fraction of the current carried by $\mathrm{K}^{+}$travels within glial cells, $\mathrm{K}^{+}$accumulates in extracellular space near the cathodal electrode, where there is a $\mathrm{K}^{+}$efflux from the glial cells.

The data points in Figure 6 show the results of one of the current-passing experiments of Gardner-Medwin and Nicholson (1983). The points show the increase in $\left[\mathrm{K}^{+}\right]_{0}$ at various depths within the cerebellum after passage of a $2,200 \mu \mathrm{A} \mathrm{cm}^{-2}$ current for $20 \mathrm{sec}$. The smooth curves (Fig. 6a,b) are simulations of the experiment using our computer model. The curves were fit to the data points by varying gglia and $\alpha_{\text {glia. }}$. These two parameters together determine the fraction of the $\mathrm{K}^{+}$current passing through the glial cell as well as the glial cell space constant. Curves $a$ and $b$ in Figure 6 are based on identical simulations except for the treatment of the fluid bathing the surface of the cerebellum. In Figure $6 a, \alpha=100$ for $\mathrm{r}<0$, simulating the perfusion (and presumed mixing) of the fluid over the cerebellar surface (the condition used in the experiment), while in Figure $6 \mathrm{~b} \alpha=1$ for $\mathrm{r}<0$, which would more accurately reflect experimental conditions if there were a large unstirred layer of fluid adjacent to the brain surface. Trace b fits the data point at $\mathbf{r}=0$ more closely than does trace $\mathbf{a}$, suggesting that a significant unstirred layer of fluid was, in fact, present during the experiment. It is interesting to note that trace $b$ provides a more satisfactory fit to all of the data points than do the analytical simulations of the experiment provided by Gardner-Medwin and Nicholson. 


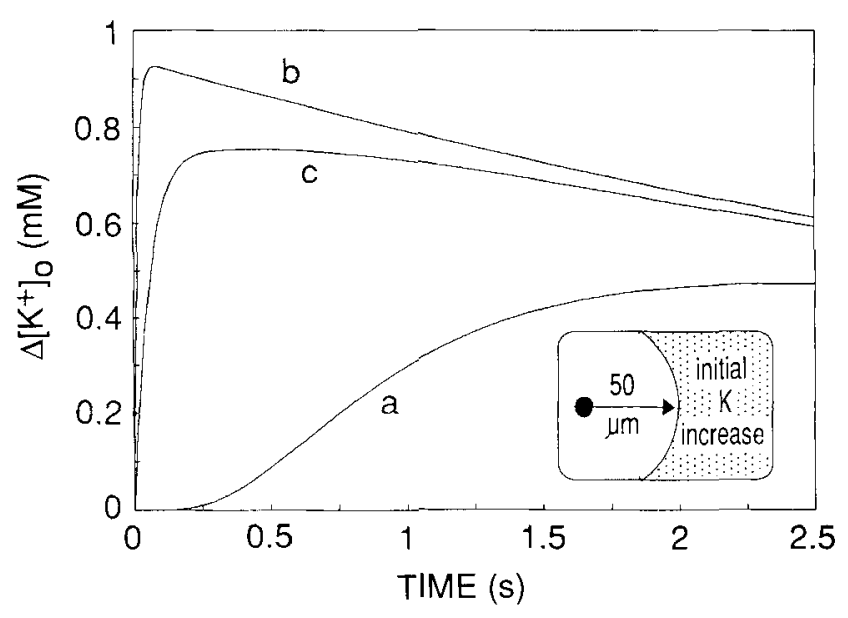

Fig. 7. Simulation of the transfer of $\mathrm{K}^{+}$to a blood vessel by glial cel $\mathrm{K}^{+}$siphoning. $\Delta\left[\mathrm{K}^{+} \mathrm{l}_{\mathrm{o}}\right.$ at the vessel wall is plotted as a function of time following an increase in $\left[\mathrm{K}^{+}\right]_{0}$ within the brain. The blood vessel is centered at $r=0$ and is assumed to have 0 radius. [ $\left.\mathrm{K}^{+}\right]_{0}$ is raised by $\mathrm{mM}$ at $\mathrm{t}=0$ for $\mathbf{r}>50 \mu \mathrm{m}$, as indicated in the inset. This initial condition simulates a blood vessel at the center of a region of neurona inactivity (radius: $50 \mu \mathrm{m}$ ) surrounded by a region of uniform neurona activity that extends to the boundary of the model $(r=350 \mu \mathrm{m})$. a Diffusion through extracellular space acts alone to transfer $\mathrm{K}^{+}$from the region of raised $\left[\mathrm{K}^{+}\right]_{0}$ to the vessel wall $\left(\mathrm{g}_{\mathrm{glia}}=0\right)$. b,c: Diffusion and $\mathrm{K}^{+}$siphoning through the glial cell act together to transfer $\mathrm{K}^{+}$to the vessel wall. $g_{g l i a}=0.31$ for $r>0$. In $b$, $g_{g l i a}=42$ at $r=0$ (the glial cell endfoot terminating on the blood vessel has high $\mathrm{K}^{+}$conduc tance relative to other cell regions). In $\mathrm{c}, \mathrm{g}_{\mathrm{glia}}=0.31$ at $\mathbf{r}=0\left(\mathrm{~K}^{+}\right.$ conductance is uniformly distributed throughout the cell). $\alpha=0.2$ for $r>0$ and $\alpha=0.0002$ and $\lambda^{2}=100$ at $r=0$, simulating the narrow, restricted extracellular space between the endfoot and the blood vesse wall. The simulations indicate that $\mathrm{K}^{+}$siphoning by glial cells signif icantly enhances the transport of $\mathrm{K}^{+}$to blood vessels from regions of raised $\left[\mathrm{K}^{+}\right]_{0}$

\section{Hypothetical Simulations}

The usefulness of our model is not limited to the sim ulation and analysis of previously performed experiments. Of greater importance, perhaps, is the testing of hypotheses that are difficult or impossible to evaluate experimentally. For instance, Paulson and Newman (1987) have suggested that $\mathrm{K}^{+}$current flow through astrocytes may regulate cerebral blood flow in response to changes in neuronal activity. Blood vessels within the brain are surrounded by astrocyte endfeet. $\mathrm{K}^{+}$released from active neurons will generate a $\mathrm{K}^{+}$current flow through astrocytes that will be preferentially shunted (siphoned; Newman et al., 1984) from the high conductance astrocyte endfeet onto the surface of the blood vessels. This $\mathrm{K}^{+}$, in turn, may dilate the vessels, which are sensitive to changes in $\left[\mathrm{K}^{+}\right]_{\mathrm{o}}$ (McCulloch et al., 1982).

We have evaluated the effect of $\mathrm{K}^{+}$current flow through astrocytes on the buildup of $\left[\mathrm{K}^{+}\right]_{0}$ at a blood vessel wall in simulations illustrated in Figure 7 . We assumed cylindrical symmetry around a blood vessel and measured the increase in $\left[\mathrm{K}^{+}\right]_{0}$ at the surface of the vessel following an imposed increase in $\left[\mathrm{K}^{+}\right]_{0}$ within the brain of $1 \mathrm{mM}$ at $\mathrm{t}=0$ and at $\mathbf{r}>50 \mu \mathrm{m}$. If diffusion through extracellular space alone acts to transport $\mathrm{K}^{+}$ from the site of the initial $\left[\mathrm{K}^{+}\right]_{0}$ increase to the blood vessel (Fig. $7 \mathrm{a}$ ), $\left[\mathrm{K}^{+}\right]_{0}$ at the vessel wall builds up slowly over several seconds. If, however, $\mathrm{K}^{+}$siphoning currents through glial cells also function to transfer the $\mathrm{K}^{+}$to the vessel (Fig. $7 \mathrm{~b}, \mathrm{c}),\left[\mathrm{K}^{+}\right]_{0}$ at the vessel wall builds up more rapidly and to significantly higher peak levels. In trace $5 \mathrm{~b}, 50 \%$ of total astrocyte membrane conductance is assumed to lie at the endfoot (adjacent the vessel) while in Figure $7 \mathrm{c}$, cell $\mathrm{K}^{+}$conductance is spatially uniform (the endfoot contains $0.738 \%$ of total cell conductance). The simulations demonstrate that $\mathrm{K}^{+}$current flow through astrocytes significantly augments the buildup of $\left[\mathrm{K}^{+}\right]_{\mathrm{o}}$ at blood vessels following a $\left[\mathrm{K}^{+}\right]_{0}$ increase at some distance from the vessel wall. This phenomenon is most effective when a large fraction of the cell conductance is localized to the endfoot but is still efficacious when endfoot conductance is low.

One final simulation of $\mathrm{K}^{+}$dynamics and glial cell function illustrates the utility of our model when simulating a complex system. Miller and Dowling (1970) first suggested that current flow through the Müller cell, the principal glial cell of the retina, generates the b-wave of the electroretinogram (ERG). b-Wave current is thought to arise in response to light-evoked variations in $\left[\mathrm{K}^{+}\right]_{0}$ within the retina. We have previously simulated this "Müller cell" hypothesis of b-wave generation in an early version of our model (Newman and Odette, 1984). Since the publication of that paper, experimental work from a number of laboratories have given us more accurate values of many essential system parameters, including the magnitude and spatial distribution of $\mathrm{g}_{\mathrm{glia}}$ (Newman, 1985, 1987), values of $\alpha$ in different retinal layers (Karwoski et al., 1985a), and the magnitudes of light-evoked $\left[\mathrm{K}^{+}\right]_{0}$ increases in the outer and inner plexiform layers (Karwoski et al., 1985b).

Figure 8 illustrates a simulation of $b$-wave generation that incorporates our best current estimates of relevant retinal tissue parameters. The figure shows the distribution of $\left[\mathrm{K}^{+}\right]_{\mathrm{o}}, \mathrm{CSD}$, and extracellular voltage as a function of retinal depth at $t=720 \mathrm{~ms}$, the peak of the b-wave response in the simulation. Variations in $\left[\mathrm{K}^{+} \mathrm{l}_{\mathrm{o}}\right.$ (Fig. 8A) are generated by $\mathrm{K}^{+}$sources at $16-30 \%$ and 56-59\% retinal depth and by a $\mathrm{K}^{+}$sink at $71-75 \%$ retinal depth. These variations in $\left[\mathrm{K}^{+}\right]_{0}$ generate an influx of $\mathrm{K}^{+}$into the glial cell throughout much of the retina (Fig. 8B, negative CSD values) and a $\mathrm{K}^{+}$efflux from the endfoot of the glial cell at $0 \%$ retinal depth. These currents, in turn, generate a negative intraretinal voltage (Fig. 8C) which peaks at 58\% retinal depth (within the outer plexiform layer). The results of this simulation indicate that the Müller cell hypothesis can account, at least qualitatively, for the generation of the b-wave (but see below).

\section{DISCUSSION}

The tests we performed on various aspects of our numerical model of $\mathrm{K}^{+}$dynamics indicate that its performance closely matches that predicted from analytical equations. Such processes as diffusion through extracellular space (Fig. 2), $\mathrm{K}^{+}$current flow through glial cells (Fig. 3), and passive and active $\mathrm{K}^{+}$uptake (Fig. 4) all produce results that are nearly identical to those predicted analytically.

However, these tests do not guarantee that our model can accurately predict the actual fate of $\mathrm{K}^{+}$within the 

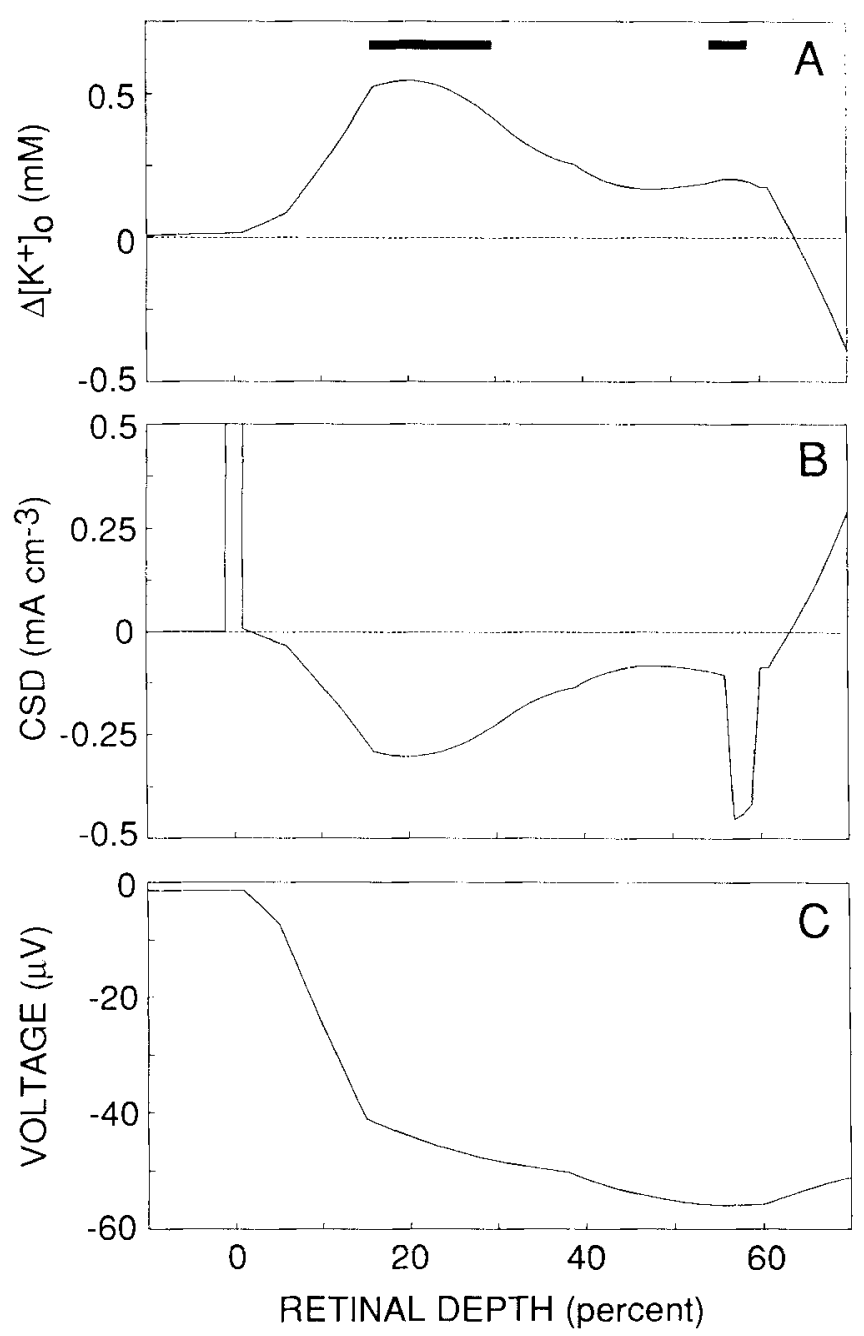

Fig. 8. Simulation of the generation of the b-wave of the electroretinogram. Variations in $\left[\mathrm{K}^{+}\right]$, current source-density (CSD), and extracellular potential are plotted as a function of retinal depth at $\mathrm{t}=720$ ms. A: $\mathrm{K}^{+}$sources in the inner and outer plexiform layers (indicated by the long and short bars above the curve) and a $\mathrm{K}^{+}$sink in the inner segment layer (not shown) give rise to variations in $\left[\mathrm{K}^{+}\right]_{0^{-}}$B: This $\left[\mathrm{K}^{+}\right]_{0}$ distribution generates an influx of $\mathrm{K}^{+}$current (negative CSD values) into the glial cell at some retinal depths and an efflux (positive CSD values) at other depths. The large current source at $0 \%$ depth and the large current sink at 56-59\% depth occur because gglia is greater in these regions than in other regions of the cell. The CSD value at $0 \%$ depth, which is off scale, equals 9.20. C: Current flow through the glial cell generates a voltage drop through extracellular space. This voltage drop establishes a potential across the retina, the proposed source of the b-wave of the ERG. Values of $\alpha$ and $g_{g l i a}$ are as follows (format: retinal layer name, percent retinal depth, $\left.\alpha, \mathrm{g}_{\mathrm{glia}}\right)$ : inner limiting membrane/endfoot, $0-1 \%, 1.0,101$; nerve fiber layer, 1-5\%, 0.06, 0.077; ganglion cell layer, 6-15\%, .024, 0.077; inner plexiform layer, 16-38\%, $0.107,0.077$; inner nuclear layer, 39-55\%, 0.028, 0.077; outer plexiform layer, 56-59\%, 0.107, 0.33; outer nuclear layer, 60-70\%, 0.028, 0.077; subretinal space, $70-100 \%, 0.116$, no glial cell; retinal pigment epithelium, 101-106\%, 0.0007 , no glial cell.

CNS once it is released from neurons. To do that, the relevant parameters of neural tissue must be known accurately. Unfortunately, values of such crucial parameters as the magnitude and distribution of glial cell membrane conductance and the dynamics of passive and active $\mathrm{K}^{+}$uptake are not known with any great accuracy. Without such information, the process of $\mathrm{K}^{+}$regu- lation within the CNS cannot be described quantitatively.

In addition, several simplifying assumptions used in our model may introduce inaccuracies in the simulations. These simplifying assumptions include the following. 1) Active uptake in the model (equation 8) incorporates only a simple, linear dependency of pump activity on $\left[\mathrm{K}^{+}\right]_{0}$. The actual $\left[\mathrm{K}^{+}\right]_{0}$ dependency of pump activity is undoubtedly more complex. Indeed, different $\mathrm{Na}^{+} \cdot \mathrm{K}^{+}$ATPases are believed to have different $\left[\mathrm{K}^{+}\right]_{0}$ dependencies (Franck et al., 1983). In addition, the model does not treat the effect of the depletion of intracellular $\left[\mathrm{Na}^{+}\right]$or the buildup of intracellular $\left[\mathrm{K}^{+}\right]$, both a consequence of prolonged pump activity, on the rate of active uptake. 2) Intracellular glial cell $\left[\mathrm{K}^{+}\right]$is assumed to remain constant in the model, although it has been shown experimentally to vary with neuronal activity (Ballanyi et al., 1987; Coles and Tsacopoulos, 1979). Variations in $\left[\mathrm{K}^{+}\right]_{\mathrm{i}}$ may alter the magnitude of spatial buffer currents. 3) The model does not take account of the movement of water between extracellular and intracellular compartments, a process accompanying passive $\mathrm{K}^{+}$uptake (Dietzel et al., 1980). The movement of water leads to changes in $\alpha$ and thus to variations in $\left[\mathrm{K}^{+}\right]_{o}$ (Dietzel et al., 1980). 4) The model assumes that extracellular and intracellular counterions have mobilities equal to those of $\mathrm{Na}^{+}$and $\mathrm{K}^{+}$. Thus, diffusion potentials have been ignored. However, the principal ions in extracellular space, $\mathrm{Na}^{+}$and $\mathrm{Cl}^{-}$, have mobilities that differ by $50 \%$. In cytoplasmic space, which contains large organic anions, the differential in ion mobilities is even larger. Thus significant diffusion potentials most likely occur following local variations in ion concentrations. (As noted above, however, $\left[\mathrm{K}^{+}\right]_{i},\left[\mathrm{Na}^{+}\right]_{0}$, and $\left[\mathrm{Cl}^{-}\right]_{0}$ in the model are assumed to remain constant.)

Although the limitations enumerated above are significant, we believe that they are of secondary importance in understanding $\mathrm{K}^{+}$dynamics in the CNS. Other processes, including diffusion, spatial buffering, passive uptake, and active uptake (the simplified form included in the simulations) will play a dominant role in regulating $\left[\mathrm{K}^{+}\right]_{\mathrm{o}}$.

In spite of possible limitations of our simulations of $\mathrm{K}^{+}$dynamics, our model is not without interest. Indeed, the few simulations described above suggest several promising avenues of research. For instance, the simulation of the Gardner-Medwin and Nicholson experiment (Fig. 6) raises some interesting questions. To fit their data properly, the following glial cell parameters were chosen: $g_{\text {glia }}=0.044 \mathrm{~S} \mathrm{~cm}^{-3} ; \alpha_{\text {glia }}=0.006$. The values of both of these parameters are approximately one-tenth those of previous estimates (see Paulson and Newman, 1987). The value of $\alpha_{\text {glia }}$ is particularly surprising, since glial cells are thought to occupy up to $50 \%$ of the total volume of the brain $\left(\alpha_{\text {glia }}=0.5\right.$ ). (In their own analysis of the data, Gardner-Medwin and Nicholson [1983] chose to set intracellular glial cell resistance to be 15.4-fold that of the extracellular resistance, indicating again that $\alpha_{\text {glia }}$ is very small.) The results of the simulation may be interpreted in a number of ways: 1) the effective intracellular volume (i.e., conductance) of glial cells may be much smaller than anticipated; 2) only a small fraction of glial cells may participate in the transport of $\mathrm{K}^{+}$near the surface of the brain; 3) gap junctions, which couple glial cells together, may significantly restrict the flow of $\mathrm{K}^{+}$current through the glial cell syncytium; 4) our analysis of the process that gives 
rise to $\left[\mathrm{K}^{+}\right]_{0}$ accumulation near a cathode may be incorrect; or 5) the current density within the brain during the experiment may have been less than the value given by Gardner-Medwin and Nicholson (there may have been a loss of current because of leakage at the brain surface).

Our simulation of $b$-wave generation (Fig. 8) provides a second example in which the performance of the model indicates that our understanding of $\mathrm{K}^{+}$dynamics in the CNS may be incomplete. The calculated spatial distribution of $\left[\mathrm{K}^{+}\right]_{0}$ within the retina at $t=720 \mathrm{msec}$ is shown in Figure $8 \mathrm{~A}$. Although this $\left[\mathrm{K}^{+}\right]_{\mathrm{o}}$ increase arises from two discrete $\mathrm{K}^{+}$sources (indicated by the filled bars above the trace), $\left[\mathrm{K}^{+}\right]_{0}$ in the region between the two sources is raised substantially. Experimental measurement of $\left[\mathrm{K}^{+}\right]_{\mathrm{o}}$ in retinal slices (Karwoski et al., $1985 \mathrm{~b}$ ), in contrast, shows that $\left[\mathrm{K}^{+}\right]_{0}$ increases very little in the inner nuclear layer (the retinal layer between the two $\mathrm{K}^{+}$sources). This discrepancy between model and experimental results may indicate that 1 ) estimates of $\alpha$ and/or $\lambda$ in different retinal layers are incorrect, or 2) uptake processes may play a more important role in clearing $\mathrm{K}^{+}$from extracellular space than is presently assumed.

The relative magnitudes of the proximal and distal $\left[\mathrm{K}^{+}\right]_{\mathrm{o}}$ increases (generated by the two $\mathrm{K}^{+}$sources) in the $b$-wave simulation were matched to those observed experimentally. These $\left[\mathrm{K}^{+}\right]_{0}$ increases generate a current flow through the Müller cell, which, in turn, generates a voltage gradient through extracellular space (Fig. 8C). The distribution of this voltage gradient within the retina indicates that approximately $65 \%$ of the total transretinal voltage is generated by the proximal $\mathrm{K}^{+}$ source, while the remaining $35 \%$ is generated by the distal $\mathrm{K}^{+}$source-sink combination. However, pharmacological experiments in the mudpuppy (Dick and Miller, 1985) suggest that almost the entire transretinal b-wave potential is generated by the distal $\mathrm{K}^{+}$source in this species. In addition, current-source density measurements in frog (Newman, 1980) indicate that $65 \%$ of the $\mathrm{b}$-wave is generated by the distal $\mathrm{K}^{+}$source. Thus, experimental results differ significantly from those obtained with the model. Once again, this discrepancy indicates that our understanding of $\mathrm{K}^{+}$dynamics in the CNS is far from perfect. In this instance, the simulation calls into question the Müller cell hypothesis of b-wave generation.

The examples cited above indicate some of the possible uses of our model of $\mathrm{K}^{+}$dynamics in the CNS. In the future, the model could be used to analyze a variety of experimental results. In addition, the model may prove valuable in testing hypotheses of glial cell function and $\mathrm{K}^{+}$dynamics in the CNS.

\section{ACKNOWLEDGMENTS}

This work was supported by National Institutes of Health grant EY 04077 to E.A.N. We thank Charles Nicholson, Andreas Reichenbach, and Janice Gepner for their valuable comments on the manuscript.

\section{REFERENCES}

Ames, W.F. (1969) Numerical Methods for Partial Differential Equations. Barnes and Noble, New York.
Ballanyi, K., Grafe, P., and ten Bruggencate, G. (1987) Ion activities and potassium uptake mechanisms of glial cells in guinea-pig olfactory cortex slices. J. Physiol., 382:159-174.

Bar, T. (1980) The vascular system of the cerebral cortex. Adv. Anat. Embryol. Cell Biol., 59:1-62.

Betz, A.L., Firth, J.A., and Goldstein, G.W. (1980) Polarity of the blood. brain barrier: Distribution of enzymes between the luminal and antiluminal membranes of brain capillary endothelial cells. Brain Res., 192:17-28.

Bradbury, M. (1979) The Concept of a Blood-Brain Barrier. WileyInterscience, Chichester, England

Brew, H. and Attwell, D. (1985) Is the potassium channel distribution in glial cells optimal for spatial buffering of potassium. Biophys. $J$., 48:843-847.

Carnahan, B., Luther, H.A., and Wilkes, J.O. (1969) Applied Numerical Methods. Wiley, New York.

Coles, J.A. (1985) Homeostasis of extracellular fluid in retinas of invertebrates and vertebrates. Prog. in Sensory Physiol. 6:105-138.

Coles, J.A. and Orkand, R.K. (1985) Changes in sodium activity during light stimulation in photoreceptors, glia and extracellular space in drone retina. J. Physiol., 362:415-435.

Coles, J.A. and Tsacopoulos, M. (1979) Potassium activity in photoreceptors, glial cells and extracellular space in the drone retina: Changes during photostimulation. J. Physiol., 290:525-549.

Crank, J. (1975) The Mathematics of Diffusion. Clarendon Press, Oxford. Cserr, H.F. (1986) The neuronal microenvironment. Ann. N.Y. Acad. Sci., 481:1-393.

Dick, E. and Miller, R.F. (1985) Extracellular $\mathrm{K}^{+}$activity changes relatcd to electroretinogram components. I. Amphibian (I-type) retinas. J. Gen. Physiol., 85:885-909.

Dietzel, I, Heinemann, U., Hofmeier, G., and Lux H.D., (1980) Transient changes in the size of the extracellular space in the sensorimotor cortex of cats in relation to stimulus-induced changes in potassium concentration. Exp. Brain Res., 40:432-439.

Eberhardt, W. and Reichenbach, A. (1987) Spatial buffering of potassium by retinal Muller (glial) cells of various morphology calculated by a model. Neurosciences, 22:687-696.

Franck, G., Grisar, T., and Moonen, G. (1983) Glial and neuronal $\mathrm{Na}^{+}$, $\mathrm{K}^{+}$pump. In: Advances in Neurobiology. S. Fedoroff and L. Hertz, eds. Academic Press, New York, pp. 133-159.

Gardner-Medwin, A.R. (1983) Analysis of potassium dynamics in mammalian brain tissue. J. Physiol., 335:393-426.

Gardner-Medwin, A.R. (1986) A new framework for assessment of potasslum-buffering mechanisms. Ann. N.Y. Acad. Sci., 481:287302.

Gardner-Medwin, A.R. and Nicholson, C. (1983) Changes of extracellular potassium activity induced by electric current through brain tissue in the rat. J. Physiol., 335:375-392.

Gardner-Medwin, A.R., Coles, J.A., and Tsacopoulos, M. (1981) Clearance of extracellular potassium: Evidence for spatial buffering by glial cells in the retina of the drone. Brain Res., 209:452-457.

Karwoski, C.J., Frambach, D.A., and Proenza, L.M. (1985a) Laminar profile of resistivity in frog retina. $J$. Neurophysiol., 54:1607-1619.

Karwoski, C.J., Newman, E.A., Shimazaki, H., and Proenza, L.M., (1985b) Light-evoked increases in extracellular $\mathrm{K}^{+}$in the plexiform layers of amphibian retinas. J. Gen. Physiol., 86:189-213.

Kushmerick, M.J. and Podolsky, R.J. (1969) Ionic mobility in muscle cells. Science, 166:1297-1298.

Lux, H.D. and Neher, E. (1973) The equilibration time course of $\left[\mathrm{K}^{+}\right]_{0}$ in cat cortex. Exp. Brain Res., 17:190-205.

Mastro, A.M. and Keith, A.D. (1984) Diffusion in the aqueous compartment. J. Cell Biol., 99:180s-187s.

McCulloch, J., Edvinsson, L., and Watt, P. (1982) Comparison of the effects of potassium and $\mathrm{pH}$ on the calibre of cerebral veins and arteries. Pflugers Arch., 393:95-98.

Miller, R.F. and Dowling, J.E. (1970) Intracellular responses of the Muller (glial) cells of mudpuppy retina: Their relation to b-wave of the electroretinogram. $J$. Neurophysiol., 33:323-341.

Newman, E.A. (1980) Current source-density analysis of the b-wave of frog retina. J. Neurophysiol., 43:1355-1366.

Newman, E.A. (1985) Membrane physiology of retinal glial (Müller) cells. J. Neurosci., 5:2225-2239.

Newman, E.A. (1986) High potassium conductance in astrocyte endfeet. Science, 233:453-454.

Newman, E.A. (1987) Distribution of potassium conductance in mam malian Müller (glial) cells: A comparative study. J. Neurosci., 7:24232432.

Newman, E.A., Frambach, D.A., and Odette, L.L. (1984) Control of extracellular potassium levels by retinal glial cell $\mathrm{K}^{+}$siphoning. Science, 225:1174-1175.

Newman, E.A. and Odette, L.L. (1984) Model of electroretinogram bwave generation: $\mathrm{A}$ test of the $\mathrm{K}^{+}$hypothesis. J. Neurophysiol. 51:164- 
182.

Nicholson, C. (1980) Dynamics of the brain cell microenvironment. Neurosci. Res. Prog. Bull., 18:177-322.

Nicholson C. and Phillips, J.M. (1981) Ion diffusion modified by tortuosity and volume fraction in the extracellular microenvironment of the rat cerebellum. J. Physiol., 321:225-257.

Paulson, O.B. and Newman, E.A. (1987) Does the release of potassium from astrocyte endfeet regulate cerebral blood flow? Science, 237:896898.

Pope, A. (1978) Neuroglia: Quantitative aspects. In Dynamic Properties of Glial Cells. E. Schoffeniels, E. Franck, L. Hertz, and D.B. Tower, eds. Pergamon, New York, pp. 13-20.

Somjen, G.G. (1979) Extracellular potassium in the mammalian central nervous system. Ann. Rev. Physiol., 41:159-177. 